\title{
AMINO ACID COMPOSITION AND PROTEIN QUALITY OF COMMON SRI LANKAN FEEDSTUFFS FOR GROWING PIGS
}

\author{
V. RAVINDRAN \\ Department of Animal Science, University of Peradeniya, Peradeniya.
}

(Date of receipt : 19 December 1991)

(Date of acceptance : 08 July 1992)

\begin{abstract}
A series of balanced trials, each involving eight growing pigs (average body. weight, $32 \pm 4 \mathrm{~kg}$ ), were conducted to determine the apparent protein digestibility and net protein utilization values of twelve local feedstuffs. The protein quality indices were high for soybean meal and fish meal, as indicated by high values of protein digestibility and net protein utilization. The net protein utilization value of gingelly poonac was low, probably due to its low content of lysine. The protein quality indices of cassava leaf meal and poultry litter were similar to that of coconut poonac: The digestibility and utilization of protein in ipil-ipil leaf meal were extremely low, which may be related to its mimosine and tannin contents. The amino acid composition of the feedstuffs is also reported.
\end{abstract}

\section{introduction}

Information on the protein quality of feedstuffs for pigs is of great importance to pig producers as a guide for assessing the production potential of the diets. Protein quality is a central aspect of pig feed problem throughout the worid. The situation is particularly critical in the tropical countries, where the quality of protein rather than the quantity is limiting practical feeding conditions. $1,2,3$

The protein value of a feedstuff is deperident on a balanced amino acid composition by its amino acid balance. While there are several reports on the amino acid composition of tropical feeds 4,5 , data on actual utilization of protein by pigs is scanty. The investigation reported here was designed to obtain information on the protein digestibility and utilization of twelve local feedstuffs for growing pigs. The feedstuffs included five energy supplements and seven protein supplements. The amino acid composition of the ingredients was also determined.

\section{Materials and Methocis}

Twelve separate balanced trials, each involving eight growing barrows (average body weight, $32 \mathrm{~kg}$; range, $26-40 \mathrm{~kg}$ ) were conducted. Details of the materials used and the experimental procedures employed were reported earlier. ${ }^{6}$

Pigs were housed in individual metabolic cages which had facilities for separation and collection of faeces and urine. During the adjustment period ( 5 days), after being put into the cages, only the basal diet was given. During the prelirinary period ( 5 days), the treatments were introduced and the pigs were fed twice daily with an 
amount calculated at $5 \%$ of their body weight. All diets were fed ir wet mash form (1:1 feed:water ratio). During the collection period ( 5 days), faeces were collected daily from each cage, dried at $60^{\circ} \mathrm{C}$ for 48 hours and weighed. Faecal and feed samples were bulked, ground to pass through a 60 -mesh screen and representative samples were taken for the determination of Kjeldahl nitrogen by standard procedures. $^{7}$

The urine was collected in large plastic buckets containing $60 \mathrm{ml}$ of $25 \%$ sulphuric acid: At the end of the collection period, the volume was measured and two $200-\mathrm{ml}$ samples were taken for the determination of Kjeldahl nitrogen.

\section{Amino acid analysis}

The ieed samples were hydrolysed with $6 \mathrm{~N}$ hydrochlcric acid under nitrogen at $110^{\circ} \mathrm{C}$ for $24 \mathrm{hrs}$. After evaporation in vacuo, the dried residue was dissolved in citrate buffer. Aliquots were analysed on an automatic amino acid analyser (Model TSM, Technicon Instruments, New York). ${ }^{8}$ The sulphur-containing amino acids were determined after oxidation with performic acid according to the procedure oc Moore. ${ }^{9}$ Tryphtophan was not determined since it is destroyed during acid hydrolysis.

\section{Calculations}

The apparent protein digestibility (PD) and apparent ne: protein utilization (NPU) values of the diets were calculated as follows:

$$
\text { Apparent PD }(\%)=\frac{\mathrm{N} \text { intake }- \text { Faecal N output }}{\mathrm{N} \text { intake }} \times 100
$$

$$
\text { Apparent NPU }(\%)=\frac{N \text { retention }}{\text { Nintake }} \times 100
$$

Where, $\mathrm{N}$ retention $=\mathrm{N}$ intake - Faecal $\mathrm{N}$ output - Urinary $\mathrm{N}$ output.

The apparent PD and NPU values of individual energy feedstuffs were estimated by the difference method, while those of the protein supplements were estimated by regression analysis. ${ }^{10}$

\section{Results and Discussion}

The proximate composition, mineral composition and the digestible energy contents of the feedstuffs have been reported previously. ${ }^{6}$ The amino acid contents, presented in Table 1, are expressed as percentages of protein to make the comparisons of amino acid profiles of different feedstuffs more meaningful. However, amino acids expressed as percentage of air-dry feed would be appropriate when these are used in feed formulations. For the purpose of conversion, protein should be considerea as 


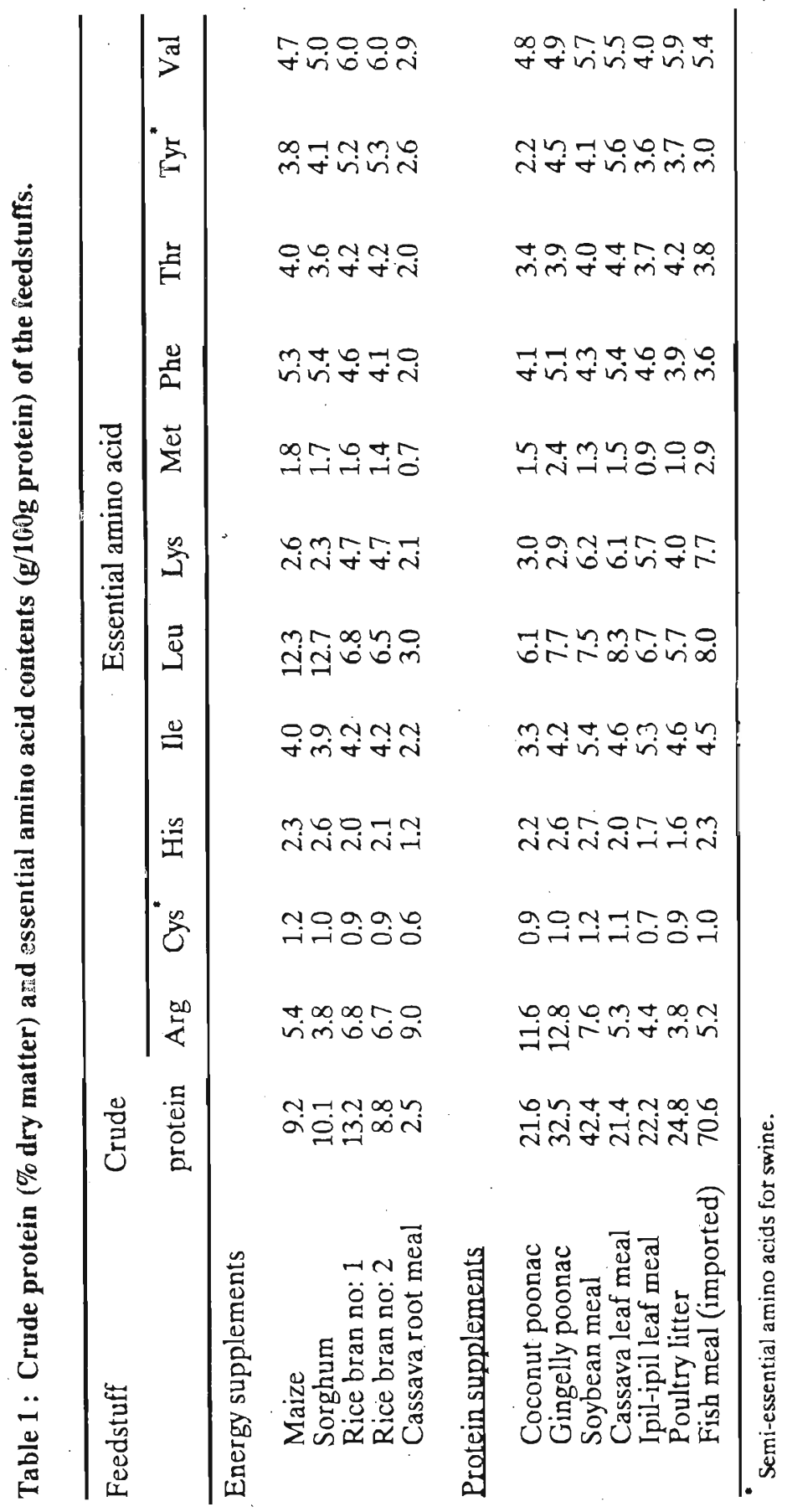


crude protein $(\% \mathrm{~N} \times 6.25)$. The exception will be the poultry litter, where the protein should be considered as $50 \%$ of the crude protein. About $56 \%$ of total nitrogen in poultry litter is known to be of non protein nitrogen origin. 11

The essential amino acid profiles of cereals, soybean meal and frsh meal are comparable to those documented by the National Research Council, Washington, USA, ${ }^{12}$ but differences were noted for the composition of by-product feeds. Coconut poonac was found to contain relatively lower amounts of lysine and sulphur-containing amino acids (methionine and cystine) than those reported for samples from elsewhere. ${ }^{12,13}$ Of the protein supplements evaluated, gingelly poonac had the highest contents of sulphur-containing amino acids, but the levels were lower than those reported for North American samples. ${ }^{12,13}$ These discrepencies probably arise from the poor processing methods generally employed under local conditions.

Consistent with earlier reports ${ }^{14,15}$, the data shows that the quality of cassava root proteir: in terms of essential amino acid contents and utilization is poor. Thus cassava-based diets must be balanced with a good source of protein for optimum animal performance. The possible replacement of coconut poonac with cassava leaf meal and ipil-ipil leaf meal has received some attention during the recent past. ${ }^{8,16-19}$ The amino acid contents of these two leaf meals were-similar to that of coconut poonac, except the level of lysine. The lysine contents of the leaf meals were almost twice that contained in coconut poonac. Relative to coconut poonac, ipil-ipil leaf meal contained low levels of methionine (Table 1). The author is unaware of any published data on the amino acid compositon of poultry litter. Poultry litter had a somewhat poorer amino acid profile compared to coconut poonac.

The apparent protein digestibility and apparent NPU values of the feedstuffs are summarized in Table '2. As anticipated, the protein digestibility values were high for fish meal (94\%), maize (89\%), soybean meal (82\%) and sorghum (78\%). The protein digestibility in coconut poonac, rice bran no:l and gingelly poonac were moderate, ranging between 64 and $68 \%$, consistent with their moderately high fibre contents. ${ }^{6}$ High fibre levels are known to depress the digestion and absorption of proteins. ${ }^{20}$ The protein digestibility values of the leaf meals were found to be low. This may be partly attributed to the high levels of tannins often associated with leaf materials. Polyphenols are known to reduce protein and amino acid digestibility, either by inactivation of enzymes such as trypsin and chymotrypsin, or by complexing with protein and making it indigestible. ${ }^{21}$

The NPU value is a reliable indicator of protein adequacy of a feedingstuff for production purposes. The NPU values confirm the superior protein quality of fish meal and soysean meal. Though the protein of gingelly poonac was $68 \%$ digestible, the NPU value was only $49 \%$. This finding is consistent with the deficiency of lysine in gingelly protein (Table 1). 
Table 2: Apparent protein digestibility (PD) and apparent net protein utilization (NPU) values of some protein supplements for growing pigs*.

Feedstuff

Apparent PD

Apparent NPU

$(\%)$

(\%)

Energy supplements

Maize

$89 \pm 1.2$

$76 \pm 2.1$

Sorghum

$78 \pm .6$

$58 \pm 3.3$

Rice bran no: 1

$66 \pm 3.1$

$52 \pm 4.2$

Rice bran no: 2

$59 \pm 4.5$

$46 \pm 5.1$

Cassava root meal

$54 \pm 1.0$

$38 \pm 2.8$

\section{Protein supplements}

Coconut poonac

Girgelly poonac

Soybean meal

Cassava leaf meal

Ipil-ipil leaf meal

Poultry litter

Fish meal (imported)

$$
\begin{aligned}
& 64 \pm 4.4 \\
& 68 \pm 5.6 \\
& 82 \pm 2.1 \\
& 56 \pm 4.8 \\
& 44 \pm 6.0 \\
& 56 \pm 5.1
\end{aligned}
$$$$
41 \pm 2.6
$$$$
49 \pm 4.2
$$$$
85 \pm 2.9
$$$$
42 \pm 3.1
$$$$
20 \pm 3.8
$$$$
40 \pm 4.0
$$$$
94 \pm 1.1
$$

- Each value represents mean \pm standard error of eight observations.

Similar NPU values obtained for the coconut poonac and poultry litter are noteworthy. The usefulness of poultry litter for supplying protein in pig diets is generally assumed to be low, due to the presence of high levels of non-protein nitrogen in poultry wastes. The NFU values observed show that the protein in poultry litter is utilized to the same degree as the coconut poonac protein. This proteir value probably arises from the spilled feed and, from microbial proteins synthesized in the hinagut of poultry and during the maturation of pouitry litter. The protein in poultry litter was $56 \%$ digestible to growing pigs. The present data is consistent with earlier reports that poultry litter can be used to replace coconut pooriac in pig rations up to dietary levels of $20 \%{ }^{22}$

Though the cassava leaf protein was less digestible than coconut poonac protein ( 56 vs $64 \%$ ), the protein utilization values were similar. The present results, along with previous reports ${ }^{16,18}$, underline the potential value of cassava leaf meal as a substitute for coconut poonac. The data also clearly demonstrate the unsuitability of ipil-ipi leaf meal as a source of protein. The protein in ipil-ipil leaves was poorly digested and utilized by growing pigs. The poor utilization value of ipi-ipil leaf mea may be attributed to its content of mimosine. 8,23 


\section{Acknowledgements}

The study was supported by research grants from NARESA (RG/88/Ag/03) and the International Foundation of Science, Sweden (IFS/B-710). The technical assistance of Mr A.R.K. Rajapakse during the conduct of metabolic trials and of Mr G. Giles, Department of Animal Science, University of British Columbia, Vancouver, Canada during amino acid analyses are acknowledged.

\section{References}

1. Nadesalingam P., Gunawardene D.D. \& Ravindran V. (1988). Performance of pigs under smallholder conditions in Sri Lanka. Proceedings of the 44 th Annual Meeting of the Sri Lankan Association for Advancement of Science, December 7-10, 1988.

2. Quijandria B. (1981). Swine production systems in Central America: limiting factors, prospects and research requirements. In: Intensive Animal Production in Developing Countries (Eds. A.J. Smith and R.G. Gunn) pp. 279-290. British Society of Animal Production, D \& J Croal Ltd., Haddington, U.K.

3. Raghavan V. (1991). Problems in mixed feed production for pigs in Malaysia. Pig News and Information 12: 61-65.

4. FAO (1972). Food Composition Tables for use in East Asia, FAO, Rome and US Dept. of Health, Education and Welfare, Washington, DC.

5. Gohl B. (1981). Tropical Feeds. FAO, Rome.

6. Ravindran V. (1992). Chemical composition and energy utilization values of common Sri Lankan feedstuffs for growing pigs. Joumal of the National Science Council of Sri Lanka 20(1):91-98.

7. AOAC (1975). Official Methods of Analysis. (11th ed.) Association of Official Analytical Chemists, Washington, DC.

8. Ravindran V. \& Wijesiri C.J. (1988). Leucaena leucocephala leaf meal as an animal feed. I. Composition and feeding value for young chicks. Sri Lankan Journal of Agricultural Sciences 25: 69-74.

9. Moore S. (1963). On the determination of cystine as cysteic acid. Journal of Biological Chemistry 238: 235-237.

10. SAS (1982). Statistical Analysis system. Statistical Analysis systems, Inc., Cary, North Carolina, U.S.A.

11. Ravindran V. \& Blair R. (1992). Feed resources for poultry production in Asia and the Pacific. 3. Animal protein sources. World's Poultry Science Joumal 48 : (In Press). 
12. NRC (1984). Nutrient Requirements of Domestic Animals, No. 2 Nutrient Requirements of Swine. ( $8 \mathrm{th}$ ed.) National Research Council, National Academy of Sciences, Washington, DC.

13. Allen R.M.D. (1991). Ingredient analysis table. Feedstuffs (USA) 63(29): 24-31.

14. Oke O.L. (1978). Problems in the use of cassava as animal feed. Animal Feed Science and Technology 3: 345-380.

15. Ravindran V., Kornegay E.T. \& Rajaguru A.S.B. (1983). Utilization of the whole cassava plant as a swine feed. World Review of Animal Production 19: 7-14.

16. Rajaguru A.S.B., Ravindran V. \& Ranaweera Banda R.M. (1978). Mianioc leaf meal as a source of protein for fattening swine. Joumal of the National Science Council of Sri Lanka 7(2): 105-110.

17. Ravindran V., Kornegay E.T., Rajaguru A.S.B., Potter L.M. \& Cherry J.A. (1986). Cassava leaf meal as a replacement of coconut oil meal in broiler diets. Poultry Science 65: 1720-1727.

1.8. Ravindran V., Kornegay E.T., Rajaguru A.S.B. \& Notter D.R. (1987). Cassava leat meal as a replacement for coconut oil meai in pig diets. Joumal of the Science of Food and Agriculture 41: 45-53.

19. Siriwardena J.A. De S. \& Ranaweera K.N.P. (1974). Manioc 'eaf meal in poultry diets. Ceylon Veterinary Joumal 22: 53-57.

20. Ravindran V., Kornegay E.T. \& Webb K.E. (1984). Effects of fiber and virginiamycin on nutrient absorption, nutrient retention and rate of passage in growing swine. Joumal of Animal Science 56: 400-408.

21. Mangan J.L. (1988). Nutritional effects of tannins in animal feeds. Nutrition Research Reviews 1: 209-231.

22. Rajaguru A.S.B., Ravindran V., Sriskandarajah N. \& Gunewardene W.V.D.A. (1978). Use of poultry litter as a protein supplement in swine rations. Joumal of the National Agricultural Society of Ceylon 15: 20-26.

23. D'Mello J.P.F. \& Acamovic T. (1989). Leucaena Leucocephala in poultry nutrition - a review. Animal Feed Science and Technology 26:1-28. 